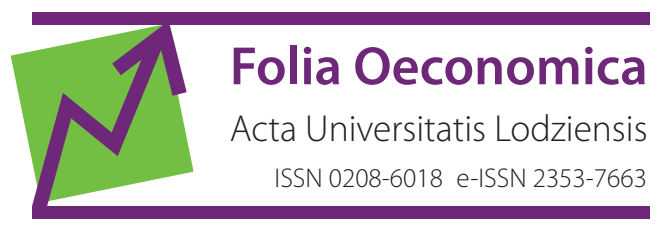

www.czasopisma.uni.lodz.pl/foe/

2(334) 2018

DOI: http://dx.doi.org/10.18778/0208-6018.334.12

\author{
Anna Piechota \\ University of Łódź, Faculty of Economics and Sociology, Department of Insurance, \\ anna.piechota@uni.lodz.pl
}

\title{
Social Security Coverage for Workers in Selected EU Countries ${ }^{1}$
}

\begin{abstract}
A worker is someone who does specific work for another person and is paid for it. In 2014, the employment rate in the EU member states was 64.9\%. This means that a large percentage of people are exposed to the so-called social risks, such as death, old age, accidents (including at work) or sickness (including occupational diseases). These risks are not only a concern for workers, who might lose their ability to work, partially or completely, but also affect other household members, such as spouses, children or parents, who might lose their breadwinner. There is no common mechanism in the EU member states to protect workers from any of those risks materialising. The purpose of this article is to identify the funding sources of social security coverage for workers, the kinds of risks covered, and the benefits offered. To do that, a comparison was drawn of various social security schemes in selected EU member states, based on the available literature and materials. The comparison shows that there is no common mechanism in the EU member states to protect workers should any of the social risks materialise, and that social security contributions are a common source of funding benefit payments.
\end{abstract}

Keywords: risk, social risk, social insurance, social security

JEL: G22, 138

${ }^{1}$ The views and opinions expressed in this paper are those of the authors and do not necessarily reflect the views and opinions of the National Bank of Poland.

The project entitled "Discussion Forum - Measurement and Evaluation of Economic and Social Phenomena" (MASEP2017) is implemented in cooperation with the National Bank of Poland within the framework of economic education. 


\section{Introduction}

A worker for the purposes of the Polish Labour Code is someone who "works pursuant to an employment contract, an appointment, an election, a designation, or a co-operative employment contract", and who has a duty to "carry out work of a particular kind for the employer, doing it at the employer's direction and at such a time and place as may be specified by the employer, with the employer having a duty to remunerate the employee for his work" (Labour Code of 1974). The EU law provides for a free movement of workers in EU member states. Except for some restrictions in terms of access to social benefits, workers on the move must be treated equally with the citizens of any member state concerned (Schmid-Drüner, 2017).

In 2015, the employment rate ${ }^{2}$ in EU member states ranged from $49.4 \%$ in Greece to $74.6 \%$ in Sweden, with the rate for Poland at $61.7 \%$. These data mean that a large percentage of people in each EU country are exposed to a large number of the so-called social risks, such as death, old age, accidents (including at work) or sickness (including occupational diseases). These risks are not only a concern for workers, who might lose their ability to work (temporarily or permanently, partially or completely), but also affect other household members, such as spouses, children or parents, who might lose their breadwinner.

Table 1. Administrative and financial techniques in delivery of social security

\begin{tabular}{|l|l|l|}
\hline \multicolumn{1}{|c|}{ Social insurance } & \multicolumn{1}{c|}{ Social provision } & \multicolumn{1}{c|}{ Social assistance } \\
\hline $\begin{array}{l}\text { A system of statutorily } \\
\text { guaranteed work-related } \\
\text { benefits which an insured } \\
\text { person can claim (apply } \\
\text { for) in case of a loss caused } \\
\text { by fortuitous events. }\end{array}$ & $\begin{array}{l}\text { Claimed benefits are funded } \\
\text { by taxes and their amounts } \\
\text { and eligibility requirements } \\
\text { are defined by statute. They } \\
\text { are available to nationals } \\
\text { of a particular country } \\
\text { who are part of a specific } \\
\text { professional or social group } \\
\text { and provided to individuals } \\
\text { on application. Applicants' } \\
\text { eligibility is means tested. }\end{array}$ \\
& for uniformed services). & \\
\hline
\end{tabular}

Source: Tendera-Właszczuk, 2010: 65

These social risks are covered by social security systems. The social security system, which is organised by a state, represents a totality of social arrangements, the aim of which is to ensure a certain standard of social security to a defined population, including employees (Szumlicz, 2010: 475-476). The social security coverage is provided using three "administrative and financial schemes (mechanisms)

\footnotetext{
${ }^{2}$ The proportion of workers in the total number of people aged 15-64.
} 
which are distinct from each other in terms of funding arrangements, the rights and duties of beneficiaries, and benefit providers. These mechanisms are social insurance (ubezpieczenie społeczne), social provision (zaopatrzenie społeczne), and social assistance (pomoc społeczna)" (Table 1).

In 2009, the social protection expenditure in the European Union accounted for $29.5 \%$ of EU-27's GDP. The largest proportion of GDP spent on social protection was reported in Denmark (33.4\%), France (33.1\%), and Sweden (32.1\%), with Latvia (16.9\%), Romania (17.1\%) and Bulgaria (17.2\%) having the lowest expenditure ratios. Poland ranked 22 among EU member states, its expenditure level at 19.7\% of GDP (Figure 1) (Statistics in focus, 2012: 1).

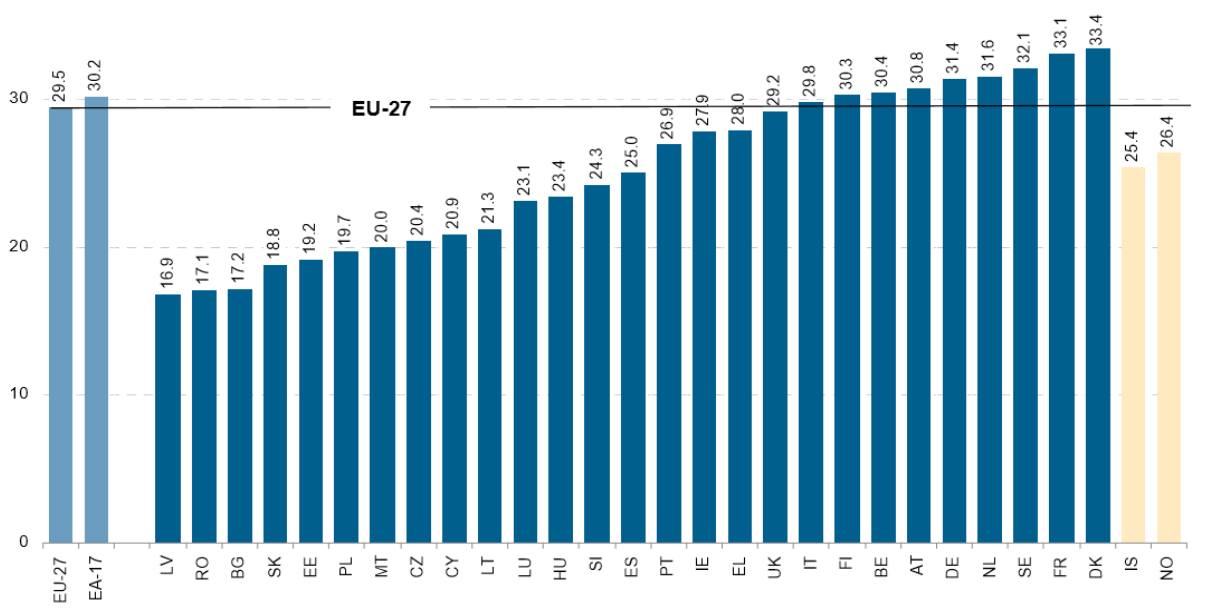

Figure 1. Expenditure on social protection as a percentage of GDP, 2009

Source: Statistics in focus, 2012

There is no common social security system in EU member states, including one that would cover employees. Instead, individual countries have various "funding schemes, portfolios of guaranteed benefits, eligibility requirements, and methods by which benefit payments are determined" (Tendera-Właszczuk, 2010: 70).

The social security coverage for workers is mainly based on social insurance, with social provision and social assistance arrangements serving to complement it. There are three prominent models of social security systems in the European Union: the Nordic model (Sweden, the Netherlands), the continental model (France, Germany), the Anglo-Saxon model (United Kingdom), and the Mediterranean model (Italy, Spain) (Szyszko-Głowacka, 2017: 4). Each model is distinguished by a different aspect. In the Nordic model, benefit payments are arranged and administered by public institutions, and they are publicly funded. The Anglo-Saxon model is characterised by scant regulation and coverage is provided primarily to the poor and those leaving the labour market. The coverage in the continental 
model depends on how much one has contributed to the system. Finally, the Mediterranean model provides a broad coverage to the elderly, but leaves a lot of social groups without any protection (Kalina-Prasznic, 2008: 28-29). Even though unique, the individual models simplify a certain whole and can be characterised in terms of certain specific features. (Szarfenberg, 2009: 2). In terms of total expenditure on social protection, EU member states spend most on old age, followed by illnesses, inability to work, and unemployment (Zgliczyński, 2017: 2).

The varied social security arrangements affect the scope of protection offered to workers and their families. The purpose of this article is to identify the funding sources of social security coverage for workers, the kinds of risks covered, and the benefits offered. To do that, a comparison study was conducted of social security schemes in selected EU member states, based on the available literature and materials.

\section{Materials and methods}

Our comparison study of the kinds of risks covered, the benefits offered, and the funding sources of social security coverage for workers involves four EU member states: Sweden, France, Italy, and Poland. The choice of the countries followed from the research question asked, which was whether (and if so, how) the specific models and levels of expenditure on social protection in the European Union have any influence on the categories of protection under examination. The selected countries operate different social security models and are characterised by high levels of expenditure on social insurance.

\section{Social security coverage for workers in Sweden}

Sweden's model of social security, the so-called Nordic model, is a rather complex system with detailed arrangements to regulate the specific life situations of the insured persons and a broad range of welfare benefits (Szyszko-Głowacka, 2017: 6). Workers in Sweden (both employed and self-employed persons) participate in a social security system which comprises: health insurance, benefits in respect of accidents at work and occupational diseases, invalidity benefits, old-age and survivors' pensions, unemployment insurance, and family benefits and parental insurance (European Commission, 2012a: 5). The system provides coverage against the risks of diseases (including occupational diseases), accidents (including at work), invalidity and old age. Benefits are funded by taxes and social security contributions paid by employers and employees/self-employed persons (the amounts of the latter varying depending on income). Benefit payments are 
administered by the Swedish Social Insurance Agency (SSIA) and the Swedish Pensions Agency (SPA). Healthcare is the responsibility of the county councils or regions (European Commission, 2012a: 6).

The risk of a worker falling ill is covered by the public healthcare system (the so-called regional system which operates on three levels: national, regional, and local). Healthcare benefits are funded by taxes (local taxation on a county level plus subsidies), social insurance funds (with employer-paid contributions at $7.7 \%$ or $7.9 \%$ of taxable income), and funds provided by citizens generally (Moks, 2010: 157). Healthcare includes general medical assistance (including doctor's visits and specialist care), hospital care, physiotherapy and any other medical treatment, dental care and medicines (European Commission, 2012a: 8). A worker who falls ill is also entitled to a cash payment that includes the employer-paid sick pay (at least $80 \%$ of the worker's pay) and a sickness cash benefit paid by the SSIA (European Commission, 2012a: 11).

The risks of a worker having an accident at work or an occupational disease are covered by a compulsory social insurance scheme. Benefits under the scheme include, but are not limited to, a sickness cash benefit, compensation, annuity, and a death benefit (European Commission, 2012a: 26).

Workers who have become invalid (lost their working capacity as a result of sickness or disability) are entitled to "sickness compensation" or "disability compensation". These benefits are funded by employees' social security contributions and taxes. A disability allowance is another benefit relating to the risk of invalidity. It is provided to those who have suffered a permanent loss of functional capacity and may be complemented by "assistance allowance/personal assistance" and "car allowance for persons with functional disorders" (European Commission, 2012a: 16-17).

Table 2. Social security coverage for workers in Sweden

\begin{tabular}{|l|l|l|}
\hline \multicolumn{1}{|c|}{ Type of coverage } & \multicolumn{1}{c|}{ Funding source } & \multicolumn{1}{c|}{ Administrator } \\
\hline $\begin{array}{l}\text { Benefits in respect of accidents } \\
\text { at work and occupational } \\
\text { diseases; invalidity benefits; } \\
\text { old-age and survivors } \\
\text { pensions; unemployment } \\
\text { insurance; family benefits and } \\
\text { parental insurance }\end{array}$ & $\begin{array}{l}\text { Universal social security } \\
\text { system with contributions paid } \\
\text { by employers and workers } \\
\text { General taxation }\end{array}$ & $\begin{array}{l}\text { Swedish Social Insurance } \\
\text { Agency (Försäkringskassan) } \\
\text { Swedish Pensions Agency } \\
\text { (Pensionsmyndigheten) }\end{array}$ \\
\hline $\begin{array}{l}\text { Healthcare } \\
\text { (Paxes } \\
\text { Social insurance contributions } \\
\text { Levies }\end{array}$ & $\begin{array}{l}\text { Swedish Social Insurance } \\
\text { Agency (Försäkringskassan) }\end{array}$ \\
\hline
\end{tabular}

Source: European Commission, 2012a; Moks, 2010: 157

The risk of old age is provided for by a three-pillar old-age pension system. The system covers everyone (aged 16 or older), including the self-employed, and is based on the first pillar (pay-as-you-go and funded old-age pension schemes) 
with pension contributions of $18.5 \%$ (of which the employer pays $10.21 \%$ until the ceiling of 8.07 times the income base amount, and 5.105\% over that ceiling, with the employee's contribution at $7.0 \%$ until the ceiling of 8.07 times the income base amount) (Poteraj, 2008: 31).

\section{Social security coverage for workers in France}

France operates what is called the continental system of social security. The system is very extensive and differentiated, and is characterised by a large proportion of expenditure for old-age pension and incapacity benefits (Szyszko-Głowacka, 2017: 12). The French social security system is based on solidarity and has the following four branches: a) the sickness, maternity, invalidity and death branch; b) the accidents at work and occupational diseases branch; c) the old age and widowhood branch; and d) the family branch (Mutual Information System on Social Protection, 2017). With respect to workers, the system is composed of the general insurance scheme, the special employee schemes, the unemployment scheme and the mandatory supplementary pension schemes (Szyszko-Głowacka, 2017: 14). Contributions are paid in different amounts by both workers and employers.

The social security coverage protects workers against risks associated with sickness, maternity, invalidity, death, occupational accidents, occupational diseases, and old age. A worker who has become invalid may apply for an incapacity pension (invalidity pension). Workers may add to their incapacity pensions by taking out supplementary insurance. The old-age risk is compensated by an old-age pension, which comprises of two elements: a basic benefit under the general scheme and a supplementary benefit, assuming there is entitlement to a minimum pension. If a worker dies, a survivor's benefit can be claimed by the surviving spouse aged 55 or more. Maternity or paternity insurance covers all costs linked to the pregnancy and confinement and provides cash benefits during the maternity leave. Workers who have fallen ill are entitled to cash benefits. While healthcare is based on general health insurance, a certain share of its costs is funded by patient co-payments. For additional health protection, supplementary insurance cover can be taken individually or via employer-purchased group schemes. This kind of insurance can fully or partially cover co-payments for healthcare services and also provide extra cash benefits to daily allowances (European Commission, 2012b: 7-8).

The responsibility for the organisation and payment of benefits associated with the risks of sickness, maternity, invalidity, death, occupational accidents, occupational diseases and old age lies with the National Sickness Insurance Fund for Employees (Caisse nationale d'assurance maladie des travailleurs salariés, CNAMTS). The old-age risks are managed by the National Old-Age Insurance Fund (Caisse nationale d'assurance vieillesse, CNAV) and the Pension Insurance 
and Health at Work Fund (Caisse d'assurance retraite et de la santé au travail, CARSAT). While the respective funds collect contributions and pay out benefits, the tasks of supervising them and controlling their spending are vested in the Central Agency for Social Security Bodies (Agence Centrale des Organismes de Sécurité Sociale, ACOSS) (Mutual Information System on Social Protection, 2017).

The workers' social risks are additionally covered by group schemes, both mandatory and voluntary. These are provided by employers or taken out individually and mostly relate to old-age, health and invalidity insurance (Szyszko-Głowacka, 2017: 15). In terms of the old-age risk and the future benefits relating to it, the basic old-age pension insurance is complemented by mandatory insurance schemes for employees, which can be supplemented with individual insurance schemes $(\mathrm{Mu}$ tual Information System on Social Protection, 2017) (Table 3).

Table 3. Social security coverage for workers in France

\begin{tabular}{|l|l|l|}
\hline \multicolumn{1}{|c|}{ Type of coverage } & \multicolumn{1}{c|}{ Funding source } & \multicolumn{1}{c|}{ Administrator } \\
\hline $\begin{array}{l}\text { Maternity benefits, invalidity } \\
\text { and survivors' benefits, death } \\
\text { benefits } \\
\text { Old-age pension insurance }\end{array}$ & $\begin{array}{l}\text { General mandatory insurance } \\
\text { system. Contributions paid } \\
\text { by employers and workers } \\
\text { General taxation }\end{array}$ & $\begin{array}{l}\text { Central Agency for Social } \\
\text { Security Bodies (Agence } \\
\text { centrale des organismes } \\
\text { de sécurité sociale, ACOSS) }\end{array}$ \\
\hline Health insurance & $\begin{array}{l}\text { Contributions } \\
\text { Privately-funded under } \\
\text { co-payment arrangements } \\
\text { or supplementary insurance } \\
\text { schemes }\end{array}$ & $\begin{array}{l}\text { Primary Sickness Insurance } \\
\text { Fund (Caisse Primaire } \\
\text { D'Assurance Maladie, CPAM) }\end{array}$ \\
\hline
\end{tabular}

Source: System ubezpieczeń społecznych we Francji, 2011; European Commission, 2012b

\section{Social security coverage for workers in Italy}

The Mediterranean model, whose features are found in the Italian social security system, is based on the concept of welfare state. Its workers' insurance scheme is diversified and has no universal criterion, with the result that while specific social groups (e.g. state officials) are provided a broad cover, other groups are deprived of protection (e.g. young people or the long-term unemployed) (Karpowicz, 2006: 5).

The social security coverage protects workers against numerous social risks, including those relating to invalidity, old age, maternity, accidents at work, sickness or occupational diseases. A worker who has become invalid may apply for an incapacity pension; those whose working capacity is reduced permanently may claim an invalidity allowance (for up to 3 years). The old-age risk is compensated by an old-age benefit (either an old-age pension or an early pension). If a work- 
er dies, his or her closest surviving family members (spouse, children, parents) may claim a survivors' benefit. Workers who have fallen ill are entitled to a cash benefit in the form of a daily allowance. In case of maternity, a worker is entitled to a five-month maternity leave, spanning the period before and after childbirth (European Commission, 2012c: 13).

Healthcare is delivered by local providers which are supervised by the relevant regional and municipal authorities. The responsibility for healthcare resources lies with the Ministry of Health. Old-age benefits are the competence of a special administration, called the National Institute for Social Security (Istituto Nazionale della Previdenza Sociale, INPS), which handles mandatory social insurance and is responsible for the collection of contributions and the provision of benefits. The available benefits are: old-age pensions (payable once the retirement age and the length of service have been achieved, with two options available, namely that of the old-age pension or the early pension), incapacity or survivors' pensions, invalidity allowances, and incapacity allowances relating to sickness or maternity; civil servants are ineligible for the last two benefits but they keep their remuneration (Mutual Information System on Social Protection, 2017; Mackiewicz, 2015). The risks relating to accidents at work, occupational diseases, health problems, invalidity or rehabilitation are covered by mandatory social insurance. Contributions and benefits are administered by the National Institute for Insurance against Accidents at Work (Istituto Nazionale per l'Assicurazione contro gli Infortuni sul Lavoro, INAIL) (Mackiewicz, 2015).

Table 4. Social security coverage in Italy

\begin{tabular}{|l|l|l|}
\hline \multicolumn{1}{|c|}{ Type of coverage } & \multicolumn{1}{|c|}{ Funding source } & \multicolumn{1}{c|}{ Administrator } \\
\hline $\begin{array}{l}\text { Sickness cash benefits, } \\
\text { maternity benefits, invalidity } \\
\text { benefits, old-age pensions and } \\
\text { benefits, survivors' benefits, } \\
\text { benefits in respect of accidents } \\
\begin{array}{l}\text { at work and occupational } \\
\text { diseases, family benefits }\end{array}\end{array}$ & $\begin{array}{l}\text { General mandatory insurance } \\
\text { system } \\
\text { Contributions paid } \\
\text { by employers and workers }\end{array}$ & $\begin{array}{l}\text { National Institute for Social } \\
\text { Security (Istituto Nazionale } \\
\text { della Previdenza Sociale, } \\
\text { INPS) } \\
\text { National Institute for the } \\
\text { Insurance against Accidents } \\
\text { at Work (Istituto Nazionale } \\
\text { per l'Assicurazione contro gli } \\
\text { Infortuni sul Lavoro, INAIL) }\end{array}$ \\
\hline Health insurance & & $\begin{array}{l}\text { National Health Service } \\
\text { Servizio Sanitario Nazionale, } \\
\text { SSN). }\end{array}$ \\
\hline
\end{tabular}

Source: European Commission, 2012c 


\section{Social security coverage for workers in Poland}

Workers in Poland derive their entitlement to social security from Article 67(1) of the country's 1997 Constitution, which provides that "A citizen shall have the right to social security in case of incapacity to work due to illness or invalidity and after attaining the retirement age". Social security is available to all citizens and forms a part of the state's social policy with its underlying social insurance, social provision and social assistance schemes (Zabezpieczenie spoleczne w Polsce, 2015: 8).

Social security is delivered to workers through social insurance schemes under which workers are treated as "the insured" pursuant to the Social Insurance System Act of 13 October 1998. The insured are primarily employees but the group also includes anyone working under contracts of agency, contracts of mandate or contracts for services, and those who carry out non-farm business activities.

In Poland, workers are covered by the following mandatory insurance: old-age pension insurance, invalidity pension insurance, sickness insurance and health insurance, with the risks covered including death, old age (survival to a certain age), and incapacity for work caused by an accident (including at work), sickness or occupational disease. Contributions are paid in different amounts by both workers and employers.

The social security system offers cash benefits (old-age and invalidity pensions, allowances, etc.) to beneficiaries, including the insured persons and, in some cases, their family members (e.g. survivors' pension). The access to benefits in kind, which are benefits offered under health insurance (doctor's or nurse's advice, hospital treatment, rehabilitation, etc.) is organized by the National Health Fund (NFZ) (Table 5).

Table 5. Social security coverage for workers in Poland

\begin{tabular}{|l|l|l|}
\hline \multicolumn{1}{|c|}{ Type of coverage } & \multicolumn{1}{c|}{ Funding source } & \multicolumn{1}{c|}{ Administrator } \\
\hline $\begin{array}{l}\text { Old-age, invalidity, sickness } \\
\text { and accident insurance }\end{array}$ & $\begin{array}{l}\text { Insurance contributions, } \\
\text { payable by employers and } \\
\text { workers }\end{array}$ & $\begin{array}{l}\text { Social Insurance Institute } \\
\text { (ZUS) }\end{array}$ \\
\hline Health insurance & $\begin{array}{l}\text { Insurance contributions, } \\
\text { payable by workers }\end{array}$ & National Heath Fund (NFZ) \\
\hline
\end{tabular}

Source: Zabezpieczenie społeczne w Polsce, 2015: 20, 24, 130 


\section{Comparison}

In all the countries under analysis, the social security protection for workers covers invalidity, old age, death, sickness, maternity/paternity, accidents at work and occupational diseases. The support provided includes both cash benefits and benefits in kind.

The risks of invalidity, old age and death are covered by cash benefits. The risk of invalidity is compensated by a cash benefit (invalidity pension or invalidity allowance) available if a worker is found to have their working capacity permanently reduced. The old-age risk is covered by mandatory insurance, with future benefits depending on the worker's income and the length of insurance. All countries provide old-age pension to workers, with minimum or early pension options. The old-age pension can be supplemented with benefits from other sources under the two- (France, Italy) or three-pillar pension systems (Sweden, Poland).

If an insured dies, a cash benefit is available in the form of a "survivors' pension", which replaces the income the family of the deceased has lost. The worker's closest family members, most often his or her spouse, are the primary beneficiaries. Funding is through insurance contributions but public funds can also be used as a supplementary source (Sweden). Table 6 below shows the benefits available to workers to cover the risks of invalidity, old age and death.

Both cash and non-cash benefits are offered to cover the risks relating to sickness, maternity/paternity, accidents at work and occupational diseases. As far as the risk of sickness is concerned, benefits are paid over varying periods of time in different countries, Poland being the only country to provide them from the first day of sickness. The amount of the benefit depends on the income. Benefits in kind are a necessary additional element in the process of recovery. In that respect, all countries offer healthcare (including rehabilitation) but only Italy and Poland do not require patient co-payments for healthcare services. Additional healthcare costs are paid in Sweden and France; workers can cover them by taking out supplementary insurance. The maternity or paternity protection for workers involves cash benefits and specific healthcare before and after childbirth. Cash benefits are paid during a maternity leave, the length of which varies from country to country (the leave is mandatory in Italy). Healthcare services are free in Italy, Poland and Sweden. In France, workers can expect to be reimbursed for the costs of pregnancy and childbirth. In all the countries concerned, accidents at work, occupational diseases or death entitle workers to cash benefits and healthcare services under social security schemes. The list of benefits is quite comprehensive and includes sickness benefits/allowances, incapacity pensions or survivors' pensions or allowance if a worker dies. All countries provide access to healthcare services, including rehabilitation, medical devices, prostheses and medicines. Table 7 provides a comparative overview of benefits available to workers to cover the risks relating to illness, maternity/paternity, accidents at work and occupational diseases. 
Table 6. Social security benefits in respect of invalidity, old age and death in selected EU countries

\begin{tabular}{|c|c|}
\hline Country & Available benefits as part of the social security coverage for workers \\
\hline \multicolumn{2}{|r|}{ Invalidity /disability (permanent incapacity to work) } \\
\hline Sweden & $\begin{array}{l}\text { - "Sickness compensation" - available where working capacity is permanently } \\
\text { reduced by } 25 \% \text {. } \\
\text { - "Activity compensation" - available where there is a long-term loss of working } \\
\text { capacity. } \\
\text { - "Disability allowance" - available where there is a permanent loss of functional } \\
\text { capacity. } \\
\text { - Supplementary benefits are available, including "care allowance for disabled } \\
\text { child", "assistance allowance/personal assistance", and "car allowance for persons } \\
\text { with functional disorders". }\end{array}$ \\
\hline France & $\begin{array}{l}\text { - Invalidity pension - available if the beneficiary's capacity to work is reduced } \\
\text { by } 2 / 3 \text {. Other benefits include reimbursement of healthcare costs for the } \\
\text { beneficiary or members of the beneficiary's family. }\end{array}$ \\
\hline Italy & $\begin{array}{l}\text { - "Invalidity allowance" - available if working capacity is reduced by more than } \\
\text { 2/3, paid for up to } 3 \text { years. } \\
\text { - "Incapacity pension" - available to those with permanent incapacity to work. } \\
\text { - Additionally, the insured may be eligible to receive a "personal assistance } \\
\text { allowance" if they become unable to perform the most basic daily life activities. }\end{array}$ \\
\hline Poland & - Invalidity pension due to inability to work, training pension, pension allowances. \\
\hline \multicolumn{2}{|r|}{ Old age (survival to a certain age) } \\
\hline Sweden & $\begin{array}{l}\text { - "Guaranteed pension" - available to those aged } 65 \text { or more. } \\
\text { - "Earnings-based pension" - available to those aged } 61 \text { or more, with the basic } \\
\text { pension contribution at } 16 \% \text { of pension-assessable income. }\end{array}$ \\
\hline France & - "Old-age pension". \\
\hline Italy & \multirow{2}{*}{ - “Old-age pension" or "early pension". } \\
\hline Poland & \\
\hline \multicolumn{2}{|r|}{ Death of a breadwinner } \\
\hline Sweden & $\begin{array}{l}\text { - "Child pension"/“surviving children's allowance" - available to children up to } \\
18 \text { years of age at } 30 \% \text { or } 35 \% \text { of the deceased's notional old-age pension. } \\
\text { - "Adjustment pension"/"guaranteed pension" - available to a spouse up to } 65 \text { years } \\
\text { of age at } 55 \% \text { of the deceased's notional old-age pension. }\end{array}$ \\
\hline France & $\begin{array}{l}\text { - "Survivor's pension" - available to the unmarried surviving spouse aged } \\
55 \text { or more. } \\
\text { - "Orphan benefit" - available to a child whose both parents died. }\end{array}$ \\
\hline Italy & $\begin{array}{l}- \text { "Survivors' pension" - available at up to } 100 \% \text { of the direct pension, with the } \\
\text { surviving spouse receiving } 60 \% \text {, and each child }-20 \% \text {. }\end{array}$ \\
\hline Poland & $\begin{array}{l}\text { - "Survivors' pension" - available at a minimum rate of } 85 \% \text { of the notional } \\
\text { incapacity pension due to inability to work. Beneficiaries include children and the } \\
\text { spouse. } \\
\text { - "Funeral allowance" - available to family members or other persons who have } \\
\text { paid for the funeral. }\end{array}$ \\
\hline
\end{tabular}


Table 7. Social security benefits in respect of illness, maternity/paternity, accidents at work and occupational diseases in selected EU countries

\begin{tabular}{|c|c|}
\hline Country & Available benefits as part of the social security coverage for workers \\
\hline \multicolumn{2}{|r|}{ Sickness } \\
\hline Sweden & $\begin{array}{l}\text { - Cash benefits: the employer pays "sick pay" from the second to and including the } \\
\text { fourteenth day of sickness; after that, sickness cash benefit is paid by the Swedish } \\
\text { Social Insurance Agency, and a rehabilitation allowance is also available. } \\
\text { - Benefits in kind: general medical assistance (including doctor's visits and } \\
\text { specialist care), hospital care, physiotherapy and any other medical treatment, } \\
\text { dental care and medicines. Involves co-payments. }\end{array}$ \\
\hline France & $\begin{array}{l}\text { - Cash benefits: a "daily allowance" is paid from the fourth day of sickness. } \\
\text { - Benefits in kind: co-payments under various basic schemes which cover } \\
\text { approximately } 75 \% \text { of household medical expenses; additionally, patients are } \\
\text { required to pay flat-rate co-payments for a number of medical services. }\end{array}$ \\
\hline Italy & $\begin{array}{l}\text { - Cash benefits: "a per diem allowance" paid by the employer from the fourth day } \\
\text { of illness for a maximum of } 180 \text { days. } \\
\text { - Benefits in kind: free healthcare (services of a general practitioner, specialist } \\
\text { services, hospitalisation), medicines and pharmaceutical products; there is a user } \\
\text { fee for diagnostic and laboratory tests and any hospitalisation extras have to be } \\
\text { paid for (private room, telephone, television). }\end{array}$ \\
\hline Poland & $\begin{array}{l}\text { - Cash benefits: For the first } 33 \text { days of sickness, employees continue to be paid } \\
\text { by their employer; from day } 34 \text { to day } 180 \text {, employees are entitled to "sickness } \\
\text { allowance". "Rehabilitation allowance" is available to workers who are ill for } \\
\text { longer periods. } \\
\text { - Benefits in kind: primary healthcare, specialist outpatient care, hospital care, } \\
\text { psychiatric care and treatment of addictions, medical rehabilitation, medical care } \\
\text { and nursing benefits, dental treatment and treatment in health resorts, provision } \\
\text { of medical devices, medical rescue, medicines. }\end{array}$ \\
\hline \multicolumn{2}{|r|}{ Maternity/paternity } \\
\hline Sweden & $\begin{array}{l}\text { - Cash benefits: "Parent's cash benefit", paid for a total period of } 480 \text { days. } \\
\text { - Benefits in kind: Preventive care for mothers and children and family planning } \\
\text { advice. }\end{array}$ \\
\hline France & $\begin{array}{l}\text { - Cash benefits: insurance covers all costs linked to the pregnancy and confinement } \\
\text { and provides cash benefits during the mother's pre- and post-natal leave, the } \\
\text { mother's or father's adoption leave and the father's paternity leave. }\end{array}$ \\
\hline Italy & $\begin{array}{l}\text { - Cash benefits: mandatory, paid, 5-month maternity/paternity leave before and } \\
\text { after childbirth, with compensation at } 80 \% \text { of pay; additionally, workers are } \\
\text { entitled to up to } 11 \text { months of parental leave at } 30 \% \text { of their pay. } \\
\text { - Benefits in kind: general obstetric care (pre-conception and pre-natal tests), } \\
\text { medical visits and laboratory tests for mothers and children up to the age of six. }\end{array}$ \\
\hline Poland & $\begin{array}{l}\text { - Cash benefits: "maternity allowance", which is paid for a period of between } 20 \\
\text { and } 37 \text { weeks depending on the number of children born, its amount ranging } \\
\text { from } 100 \% \text { to } 60 \% \text { of its calculation basis, and "child-minding allowance", which } \\
\text { is paid for } 14 / 60 \text { days per year and amounts to } 80 \% \text { of its calculation basis. } \\
\text { - Benefits in kind: guaranteed benefits as in the case of sickness. }\end{array}$ \\
\hline
\end{tabular}




\begin{tabular}{|c|c|}
\hline Country & Available benefits as part of the social security coverage for workers \\
\hline \multicolumn{2}{|r|}{ Accidents at work and occupational diseases } \\
\hline Sweden & $\begin{array}{l}\text { - Cash benefits: "sickness cash benefit", compensation to prevent the accident } \\
\text { or disease, annuity, death benefit. } \\
\text { - Benefits in kind: healthcare, rehabilitation. }\end{array}$ \\
\hline France & $\begin{array}{l}\text { - Cash benefits: daily allowance, pension for permanent disablement. } \\
\text { - Benefits in kind: healthcare, medicines, hospital stay, equipment and prostheses. }\end{array}$ \\
\hline Italy & $\begin{array}{l}\text { - Cash benefits: cash and supplementary benefits: daily compensation, annuity, } \\
\text { compensation for permanent physical and/or mental impairment, direct annuity } \\
\text { supplement, survivors' annuity, death grant, monthly personal assistance } \\
\text { allowance, survivors' monthly allowance. } \\
\text { - Benefits in kind: medical assistance, prostheses and medical appliances, spa and } \\
\text { thermal cures, treatments in health resorts, medical checks and forensic doctors' } \\
\text { certifications, outpatient "first aid" care. }\end{array}$ \\
\hline Poland & $\begin{array}{l}\text { - Cash benefits: sickness allowance, compensation allowance, rehabilitation benefit, } \\
\text { accident pension, invalidity pension supplants, lump-sum compensation. } \\
\text { - Benefits in kind: healthcare, rehabilitation. }\end{array}$ \\
\hline
\end{tabular}

Source: European Commission, 2012a; 2012b; 2012c

\section{Summary}

Even if they differ in details, the social security arrangements for workers are very similar in all countries under analysis. In all of them, coverage is provided through mandatory social insurance schemes. Social insurance covers the social risks: of death, of survival to a certain age (old age risk), of accidents, and of sickness (including occupational diseases). The benefits offered may compensate workers for their lost pay and they also serve as financial aid to the closest family members. The costs are paid both by the insured and the workers' employers. The amounts spent on social insurance in the countries concerned do not affect the kinds of risks covered or the benefits offered.

The country-specific social security models and levels of social insurance funding affect the way in which worker benefits are financed. All of the systems discussed rely on insurance contributions as their primary funding source for future benefits. There are significant differences in terms of other funding sources for sickness benefits, which can be funded by general or local taxes (Sweden and France) or with worker-paid fees (Sweden, France, Italy). The difference is significant because these mandatory healthcare co-payments are a burden on household income. 


\section{References}

European Commission (2012a), Your social security rights in Sweden, http://ec.europa.eu/social/ BlobServlet?docId=13776\&langId=en [accessed: 21.07.2017].

European Commission (2012b), Your social security rights in France, http://ec.europa.eu/social/ BlobServlet?docId=13750\&langId=en [accessed: 21.07.2017].

European Commission (2012c), Your social security rights in Italy, http://ec.europa.eu/social/BlobServlet?docId=13763\&langId=en [accessed: 21.07.2017].

Kalina-Prasznic U. (2008), Ekonomiczne kontrowersje wokół europejskiego modelu socjalnego, "Prace Naukowe Uniwersytetu Ekonomicznego we Wrocławiu", no. 21, pp. 25-32, http:// www.dbc.wroc.pl/Content/15473 [accessed: 30.10.2017].

Karpowicz E. (2006), Modele polityki spolecznej. Kierunki zmian polityki społecznej w Polsce, Biuro Studiów i Ekspertyz Kancelarii Sejmu, Warszawa.

Labour Code of June 26, 1997, item 66.

Mackiewicz A. (2015), System świadczeń społecznych, Ministerstwo Rozwoju, Warszawa.

Moks M. (2010), Szwedzki system ochrony zdrowia - wybrane kierunki jego reformowania, "Oeconomia Copernicana", issue 1, pp. 151-164.

Mutual Information System on Social Protection, http://www.missoc.org/INFORMATIONBASE/ informationBase.jsp [accessed: 13.07.2017].

Poteraj J. (2008), Systemy emerytalne w Europie. Przypadek Szwecji, "Współczesna Ekonomia”, no. 2(6), issue 2, pp. 19-35.

Schmid-Drüner M. (2017), Swobodny przepływ pracowników, http://www.europarl.europa.eu/ atyourservice/pl/displayFtu.html?ftuId=FTU_2.1.5.html [accessed: 25.07.2017].

Social Insurance System Code of 13 October, 1998 (No. 137, item 887).

Statistics in focus (2012), http://ec.europa.eu/eurostat/web/products-statistics-in-focus/-/ KS-SF-12-014?inheritRedirect $=$ true \&redirect $=\% 2$ Feurostat $\% 2$ Fweb $\% 2$ Fsocial-protection\%2Fpublications [accessed: 23.07.2017].

System ubezpieczeń społecznych we Francji (2011), www.copernic-avocats.pl/system-ubezpieczen-spolecznych-we-francji/ [accessed: 4.07.2017].

Szarfenberg R. (2009), Modele polityki społecznej w teorii i praktyce, http://rszarf.ips.uw.edu.pl/ pdf/modele_ps.pdf [accessed: 30.10.2017].

Szumlicz T. (2010), Ubezpieczenia w systemie zabezpieczenia społecznego, [in:] J. Monkiewicz, J. Handschke, Ubezpieczenia. Podręcznik akademicki, Poltext, Warszawa.

Szyszko-Głowacka K. (2017), Systemy ubezpieczeń społecznych w wybranych krajach UE, Zakład Ubezpieczeń Społecznych, Warszawa.

Tendera-Właszczuk H. (2010), Polityka społeczna krajów Unii Europejskiej po wschodnim rozszerzeniu, Polskie Towarzystwo Ekonomiczne, Kraków.

The Constitution of the Republic of Poland of $2^{\text {nd }}$ April, 1997.

Zabezpieczenie społeczne w Polsce (2015), Zakład Ubezpieczeń Społecznych, Warszawa.

Zgliczyński W. (2017), Polityka społeczna w państwach UE - wydatki i rozwiazania modelowe, Biuro Analiz Sejmowych, Infos no. 10(233), Warszawa. 


\section{Zabezpieczenie społeczne pracownika w wybranych państwach Unii Europejskiej}

Streszczenie: Pracownikiem jest osoba wykonująca konkretne zajęcie na rzecz innej osoby, za które w zamian otrzymuje wynagrodzenie. W roku 2014 wskaźnik zatrudnienia w krajach Unii Europejskiej wyniósł 64,9\%. Świadczy to o wysokim odsetku osób, które są narażone na tzw. ryzyka społeczne, takie jak śmierć, starość, choroba, wypadek, wypadek przy pracy czy choroba zawodowa, zagrażające nie tylko im samym (częściowa czy całkowita utrata zdolności do pracy), ale również osobom pozostającym z nimi we wspólnym gospodarstwie domowym (współmałżonkom, dzieciom, rodzicom) - przez utratę żywiciela. Nie istnieje jeden wspólny dla wszystkich krajów Unii Europejskiej mechanizm zabezpieczający pracowników przed negatywnymi skutkami realizacji ryzyk społecznych. Celem artykułu jest porównanie zabezpieczenia społecznego pracowników w wybranych państwach Unii Europejskiej.

Słowa kluczowe: ryzyko, ryzyko społeczne, ubezpieczenie społeczne, zabezpieczenie społeczne

JEL: G22, 138

\begin{tabular}{|l|l|}
\hline \multirow{2}{*}{ OPEN ACCESS } & $\begin{array}{l}\text { C by the author, licensee Łódź University - Łódź University Press, Łódź, Poland. } \\
\text { This article is an open access article distributed under the terms and conditions } \\
\text { of the Creative Commons Attribution license CC-BY } \\
\text { (http: //creativecommons.org/licenses/by/3.0/) }\end{array}$ \\
\cline { 2 - 2 } \\
Received: 2017-08-26; verified: 2017-11-16. Accepted: 2018-01-23
\end{tabular}

